\title{
Cypermethrin-Induced in vitro Alterations on Oxidative Stress and Quality of Salmo coruhensis Spermatozoa
}

\author{
Filiz Kutluyer ${ }^{1 *}$, Mehmet Kocabaş², Mine Erişiri ${ }^{3}$, Fulya Benzer ${ }^{4}$ \\ ${ }^{1}$ Fisheries Faculty Munzur University, Tunceli, TURKEY. \\ ${ }^{2}$ Department of Wildlife Ecology and Management, Karadeniz Technical University Faculty of Forestry, Trabzon, TURKEY. \\ ${ }^{3}$ Department of Basic Sciences, Fırat University, Faculty of Veterinary, Elazığ, TURKEY. \\ ${ }^{4}$ Department of Food Engineering, Munzur University, Faculty of Engineering, Tunceli, TURKEY.
}

\begin{abstract}
The use of insecticides has been increasing along with increasing agriculture activities and has caused deleterious environmental impacts. Non-target organisms in particular, including fish, are affected by pesticides. In this work, the impacts of cypermethrin (CYP) on sperm oxidative stress markers and sperm motility were investigated in vitro. The CYP concentrations were $0 \mu \mathrm{g} \mathrm{L}^{-1}$ control, ethanol), $1.025 \mu \mathrm{g} \mathrm{L}^{-1}, 2.05 \mu \mathrm{g} \mathrm{L}^{-1}$ and $4.1 \mu \mathrm{g} \mathrm{L}^{-1}$. Lipid peroxidation [Malondialdehyde (MDA)], non-enzymatic antioxidants [glutathione (GSH)] and enzymatic [superoxide dismutase (SOD), glutathione peroxidase (GSH-Px) and catalase (CAT)] activities in sperm cells were examined for determination of oxidative stress status. Our findings showed that motility and survival of sperm cells significantly decreased with exposure to CYP. Biochemical assays revealed that CAT activity and levels of MDA and, GSH increased in spermatozoa based on CYP concentration while activity of GSH-Px and SOD decreased. Consequently, spermatozoa were highly sensitive to CYP exposure. It can be deduced that CYP has the potential to disrupt sperm quality and to cause to oxidative stress in sperm cells of $S$. coruhensis.
\end{abstract}

Key words: Cypermethrin, Oxidative stress parameters, Salmo coruhensis, Sperm cell.

\section{INTRODUCTION}

Cypermethrin is a pyrethroid insecticides and non-systematic pesticide. It has been extensively used in farming activities, forestry, household insect control, horticulture, and veterinary medicine instead of organochlorines and organophosphorus insecticides. ${ }^{1-4}$ It has been especially used to control multiple crop pests. ${ }^{5}$ In addition, it has been used for welfare of human beings or structural pest management. ${ }^{6-9}$ Especially, aquatic life is influenced by toxicological impact of CYP. ${ }^{7,10-12}$ CYP may enter surface to water bodies through forest-spraying procedures, accidental overspray, agricultural use, runoff and drainage. ${ }^{3}$ As such, aquatic organisms such as fish, freshwater mussels and zooplankton species are exposed to CYP. $96 \mathrm{~h} \mathrm{LC50} \mathrm{of}$ CYP has been reported within the range of $0.4-2.8 \mu \mathrm{g} \mathrm{L}^{-1}$ and aquatic invertebrates LC50 in the range of $0.01-5 \mu \mathrm{g} \mathrm{L} \mathrm{L}^{-1} \cdot{ }^{10-13}$ Especially, salmon-bearing waterways are affected by toxicants. ${ }^{14}$ Salmonids are sensitive to natural and anthropogenic alterations of their habitats. ${ }^{15}$ Salmo corubensis is an endemic anadromus fish and only distributed in the rivers of Eastern Black Sea Region. ${ }^{16}$ In the present study we used $S$. corubensis due to the high sensitivity to CYP and the endangered status. The results of this work would contribute to reflect the potential risk of pesticide pollution towards endangered aquatic organisms.

Sperm motility is the critical functional parameter in fish for fertilization success. ${ }^{17,18}$ Especially in Salmonids sperm cells are immotile in seminal fluid and require to be
Submission Date: 19-09-2017; Revision Date: 08-11-2017; Accepted Date: 18-04-2018

DOI: 10.5530/ijper.52.4s.78 Correspondence:

Filiz Kutluyer,

Fisheries Faculty Munzur University, 62000, Tunceli, TURKEY.

Phone: +90 05544078065 E-mail: filizkutluyer@hotmail. com

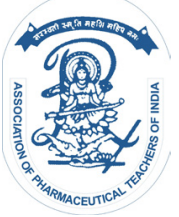

www.ijper.org 
released into the water in order to become metabolically active. ${ }^{18,19}$ As such Salmonid gametes come into direct contact with contaminants ${ }^{20}$ and negatively affected. Besides sperm quality, physiological traits are important for monitoring animal health. ${ }^{21}$ Oxidative stress is one of physiological traits and induced by anthropogenic and natural stressors, including pollutants. ${ }^{22}$ Oxidative stress-related biomarkers are used for forecasting and explaining interactions between pollutants and environmental factors. ${ }^{21,23}$ Previous studies have shown that CYP affects reproductive functions, and may cause sperm damage and immobility in different aquatic animals. ${ }^{21,24,25}$ Nevertheless the impact of CYP on the endangered trout Salmo coruhensis male gametes has not yet been analyzed. For these reasons, the present study focused on short-term $(2 \mathrm{~h})$ in vitro exposure of sperm cells of $S$. corubensis to CYP. The markers lipid peroxidation levels (MDA), non-enzymatic antioxidants (GSH) and enzymatic antioxidant activities (SOD, GSH-Px and CAT) were measured along with sperm motility.

\section{MATERIALS AND METHODS}

\section{Ethics statement}

All experiments were conducted according to the principles of the Ethics Committee for the Protection of Animals in Research of the University of Karadeniz Technical University (Protocol No: 2016/36).

\section{Chemicals}

Cypermethrin $\left(\mathrm{C}_{22} \mathrm{H}_{19} \mathrm{Cl}_{2} \mathrm{NO}_{3}\right)$ with a purity of $99.5 \%$ was purchased from the Sigma Chemical Company (St. Louis, MO, USA). All other reagents were purchased from Sigma-Aldrich (St. Louis, MO).

\section{Fish handling and sperm collection}

Six mature endangered trout males (weight: $1557.89 \pm 0.22 \mathrm{~g}$, length: $44.16 \pm 3.12 \mathrm{~cm}$ ) were randomly selected from a broodstockatnaturalphotoperiod(14L:10D) (November, 2016) in Altundere Fish Production Station Meryemana Stream, Trabzon, Turkey (407 '02.73” N-3962'96.52'W) for sperm collection. Water temperature and dissolved oxygen were $5.0 \pm 1^{\circ} \mathrm{C}$ and $8.6 \pm 0.2 \mathrm{mg} \mathrm{L}^{-1}$, respectively. After the fish were anesthetized in $0.6 \mathrm{~mL} \mathrm{~L}^{-1} 2$-phenoxyethanol, sperm samples were collected through abdominal massage and the initial male ejaculate was discarded and the external urogenital pore was wiped dry with paper towel to avoid seawater, urine, and feces contamination. Sperm samples were kept on crushed ice until use. Spermatozoa concentration was evaluated using a haemocytometer (0.1 mm depth).

\section{Sperm dilution and exposure}

CYP concentrations used in this study were $0 \mu \mathrm{g} \mathrm{L}^{-1}$ (control, ethanol), $5 \mu \mathrm{g} \mathrm{L}^{-1}, 10 \mu \mathrm{g} \mathrm{L}^{-1}$ and $15 \mu \mathrm{g} \mathrm{L} \mathrm{L}^{-1}$. CYP

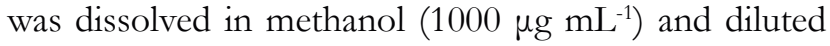
with distilled water to obtain a stock solution of $0.1 \mathrm{~g} \mathrm{~L}^{-1}$. The pooled sperm $(\mathrm{N}=6)$ was then diluted in immobilization medium $\left(\mathrm{NaCl}, 103 \mathrm{mmol} \mathrm{L}^{-1} ; \mathrm{KCl}, 40 \mathrm{mmol} \mathrm{L}^{-1}\right.$; $\mathrm{CaCl}_{2}, 1 \mathrm{mmol} \mathrm{L}^{-1} ; \mathrm{MgSO}_{4}, 0.8 \mathrm{mmol} \mathrm{L}-1$; HEPES, $20 \mathrm{mmol} \mathrm{L}^{-1} ; \mathrm{pH} 7.8$ ) to obtain a sperm density of $6 \times 10^{8}$ cells $\mathrm{mL}^{-1}$. In brief the pooled samples were exposed for $2 \mathrm{~h}$ to CYP. Each experiment condition was performed in triplicate.

\section{Spermatozoon motility}

The percentage and duration of motile spermatozoa were determined following a two-step dilution after the sperm was exposed to CYP in the immobilization medium. Immediately, this was followed by a second five-fold dilution in an activation medium $(45 \mathrm{mM} \mathrm{NaCl}$, $5 \mathrm{mM} \mathrm{KCl}, 30 \mathrm{mM}$ Tris-HCl, $\mathrm{pH}$ 8.2) ${ }^{26}$ For determination of spermatozoa motility and duration, analysis was performed in triplicate for each sample. The percentage and duration of motile spermatozoa were immediately recorded for $1 \mathrm{~min}$ after activation. The percentage of spermatozoa motility and duration of sperm samples were assessed for the motility parameters using a light microscope with a digital image processing software connected to the computer (Eclipse E50; Nikon Corporation, Tokyo, Japan). The motility rate was determined as the cell performing progressive forward movement, while motility duration was assessed as the time until forward movement stops.

\section{Lipid peroxidation and antioxidant enzyme activity}

Pooled sperm samples were centrifuged at $3000 \times g$ at $4^{\circ} \mathrm{C}$ for $10 \mathrm{~min}$ in a LD5-2B centrifuge (Beijing Shiningsun Technology, Japan) and the sperm pellet was placed in an ice bath and resuspended in $\mathrm{KCl}(1.15 \% \mathrm{~W} / \mathrm{V})$ at the 1:10 ratio. For evaluation of lipid peroxidation, thiobarbituric acid reacting substances method (TBARS) was used as described by Placer et al. ${ }^{27}$ on a spectrophotometer (UV-1800 UV-VIS, Shimadzu, Japan) at $532 \mathrm{~nm}$. MDA values expressed as nmol g-1 ${ }^{-1}$ sperm cells. SOD enzyme activity was determined by the method of Sun $e t a .^{28}$ on a spectrophotometer at $560 \mathrm{~nm}$ and expressed as $\mathrm{U} / \mathrm{mg}$ protein. GSH-Px activity was assessed by the method of Matkovics et al..$^{29}$ In brief GSH-Px activity was determined by cumene hydroperoxide and reduced glutathione (GSH) as co-substrates and the loss of GSH following enzymatic reaction at $37^{\circ} \mathrm{C}$ was measured spectrophotometrically with Ellman's reagent at $412 \mathrm{~nm}$. 
The activity was expressed as and expressed as unite per $\mathrm{mg}$ of protein ( $\mathrm{U} \mathrm{g}^{-1}$ protein) per $10^{8}$ cells. CAT activity was assessed by the method of $\mathrm{Aebi}^{30}$ on a spectrophotometer at $240 \mathrm{~nm}$. CAT activity was expressed as kat $\mathrm{g}^{-1}$ protein per $10^{8}$ cells. Reduced glutathione (GSH) was assayed by the method of Chavan et al. ${ }^{31}$ and expressed as $\mu \mathrm{mol}$ GSH $\mathrm{g}^{-1}$ sperm cells. The method is based on the capacity of sulfhydryl groups present in whole blood to react with 5, 5'-dithiobis-(2-nitrobenzoic acid) and form a yellow dye with maximum absorbance at $412 \mathrm{~nm}$. The protein content in spermatozoa was measured by method of Lowry et al. ${ }^{32}$ All antioxidant activity data were obtained in triplicate for each pooled sample.

\section{Data presentation and statistical analysis}

All measurements were conducted in triplicate. Statistical analysis were performed using SPSS 14.0 software and values were reported as mean \pm SD. ANOVA (one-way) with Duncan post hoc tests was used for assessment differences among groups. Normality and homogeneity of variance were confirmed prior to analysis. Data was subjected to a Student-Newman-Keuls post-hoc test for homogenous subsets. The level of significance was set as 0.05 .

\section{RESULTS}

Motility rate and survival of sperm cells of fresh semen were $98.38 \pm 2.5 \%$ and $43.94 \pm 4.0 \mathrm{~s}$, respectively. Motility and survival of sperm cells are shown in Figure 1. CYP significantly decreased motility and survival of sperm cells of $S$. coruhensis $(P<0.05)$. In the control, $90.3 \%$ of spermatozoa were motile while $40.6 \%$ were motile at $20.33 \mathrm{~s}$ post-activation in the group exposed to $4.1 \mu \mathrm{g} \mathrm{\textrm {L } ^ { - 1 }}$ of CYP.

Lipid peroxidation (MDA), non-enzymatic (GSH) and enzymatic (SOD, GSH-Px and CAT) activities are presented in Figure 2. A significant effect of CYP on oxidative stress indicators was observed. MDA, an indicator of antioxidant activity in fish spermatozoa, increased upon exposure to CYP at $4.1 \mu \mathrm{g} \mathrm{L}^{-1}$ and
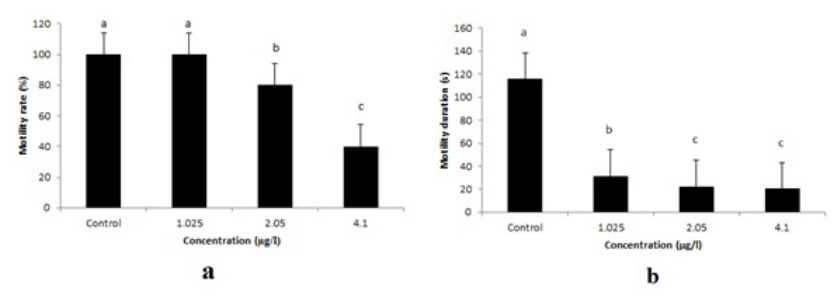

Figure 1: in vitro effects of CYP on spermatozoa a) motility rate (\%) and b) motility duration (s) in Salmo coruhensis $(n=6)$. Data are presented as means \pm SD. Superscript letters indicate significant differences among samples at the same time post-activation $(P<0.05)$.

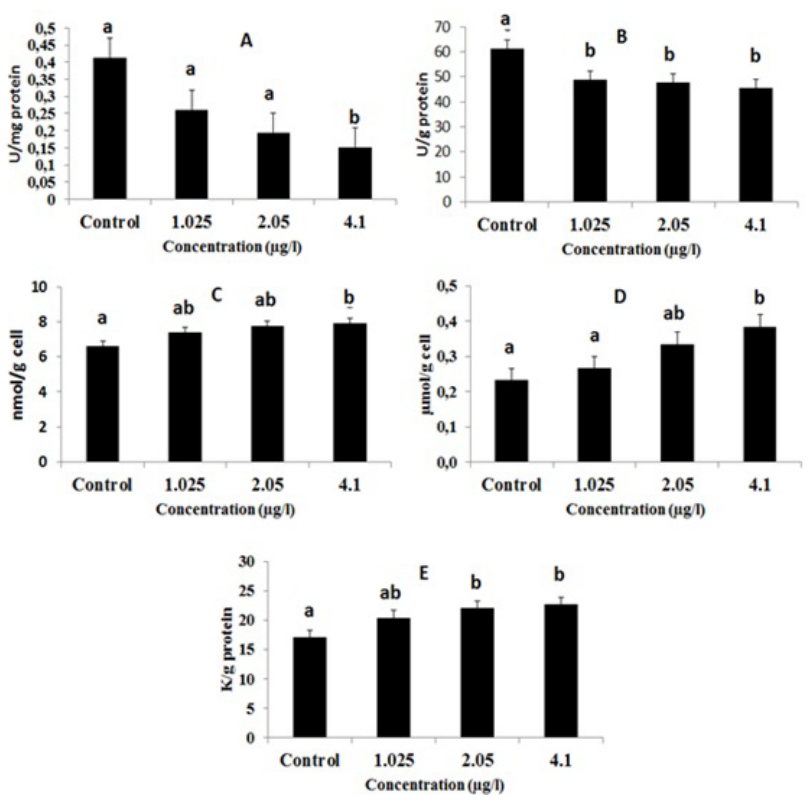

Figure 2: Effect of CYP on (A) SOD, (B) GSH-Px, (C) MDA, (D) GSH and (E) CAT of spermatozoa in Salmo coruhensis $(n=6)$. Data are presented as means \pm SD. Superscript letters indicate significant differences among samples at the same time postactivation $(P<0.05)$.

greater. Our data showed that MDA $(\mathrm{P}=0.455, P<0.05)$, CAT $(\mathrm{P}=0.036, \mathrm{P}<0.05)$, GSH $(\mathrm{P}=0.013, P<0.05)$ and levels of endangered trout $(S$. coruhensis) spermatozoa were increased by CYP and, GSH-Px $(\mathrm{P}=0.043, P<0.05)$ while SOD activity decreased $(\mathrm{P}=0.043, P<0.05)$.

\section{DISCUSSION}

To date, studies have been conducted on some aspects of reproduction in Atlantic salmon (Salmo salar L.), ${ }^{25}$ reproductive behaviour of $S$. trutta, ${ }^{22}$ histological changes in gonadotrophic cells, liver, gonads, plasma levels of estradiol-17b and 11-ketotestosterone, and sperm motility in Heteropneustes fossilis. ${ }^{26}$ haemoglobin and haematocrit of Capoeta capoeta capoeta ${ }^{33}$ oxidative status in different tissues and erythrocytes of Channa punctata and Unio elongatulus eucirrus. ${ }^{12,34}$ In studies about effect of CYP on oxidative status in tissues, it was determined that oxidative stress-related markers were influenced by CYP. In vitro sperm exposure helps in determination of direct damage of the gametes. ${ }^{35}$ The consequences of CYP exposure on oxidative stress-related biomarkers of $S$. corubensis spermatozoa have not been previously reported. A few studies have evaluated the effects of toxicants on spermatozoa of trout. ${ }^{21,36}$ Only a 
study has been examined toxic impact of CYP on spermatozoa of rainbow trout by Kutluyer et al. ${ }^{36}$ In the study, it has been reported that reactive oxygen speciesrelated stress were induced by pesticides after exposure to concentrations of CYP from 1.025 to $4 \mu \mathrm{g} \mathrm{L} \mathrm{L}^{-1}$. In agreement with the previous studies noted above, our results indicated that Malondialdehyde (MDA as indicator of lipid peroxidation and the oxidative damage products) increased in sperm cells. It can be explained by excessive production of reactive oxygen substances (ROS) and highly susceptibility to lipid peroxidation (LPO) of spermatozoa. Since spermatozoon cell membranes have polyunsaturated fatty acids (PUFA) at high concentrations. Oxidative defensive enzymes activities (SOD and GSH-Px) in spermatozoa were inadequate for prevent cellular damage in this study. Transition of superoxide anion $\left(\mathrm{O}_{2}^{-}\right)$to hydrogen peroxide $\left(\mathrm{H}_{2} \mathrm{O}_{2}\right)$ might be insufficient due to decrease in SOD activity for protection from oxidative damage. ${ }^{37}$ The current study showed that CAT activities and GSH increased in sperm cells. Since GSH is the main non-protein thiol and preservative antioxidant agents against lipid peroxidation and, directly participated in the neutralization of ROS. ${ }^{38-39} \mathrm{In}$ addition, this increment might be related with defending against oxidative stress-induced toxicity based on decrease in SOD and GSH-Px.

Sperm motility is one of sperm quality parameters and important for successful fertilization and hatching. In past decade, studies about determination of sperm motility in toxicity test have been conducted due to be easy and rapid of assessment and analysis. Studies have been conducted about impact of toxicants on sperm motility of different fish species (Salmo trutta fario, Cyprinus carpio, Acipenser ruthenus, Heteropneustes fossilis, Rutilus frisii kutum, O. mykiss). ${ }^{21,26,36,40-48}$ In these studies about fish sperm, it has been reported lower spermatozoon motility with exposure to different pesticides. Singh and Singh $^{26}$ stated that sperm motility and duration of Heteropneustes fossilis were influenced by CYP and $1 \mathrm{ppm}$ was lethal on sperm motility. They suggested that decrease of sperm motility might be owing to inhibition of ATP synthesis in mitochondria. Kutluyer $e t$ al. ${ }^{36}$ determined that sperm quality of rainbow trout decreased in a dosedependent manner by CYP. They were determined that motility and duration were decreased after exposure to concentrations of CYP from 1.025 to $4 \mu \mathrm{g} \mathrm{L} \mathrm{L}^{-1}$. Consistent with these studies, motility rate and duration significantly decreased with increasing CYP concentrations in present study. This may be explained by rupture of the cell membrane and cell apoptosis and, destroying the functional integrity of the axosome and mitochondria of the sperm cells as a consequence of LPO. ${ }^{49}$

\section{CONCLUSION}

Consequently, our results clearly demonstrated that an exposure to sub-lethal insecticide concentrations can impair sperm quality of endangered trout. Biochemical assays revealed that a defensive response increased for preventing lipid oxidation. Additionally, low doses of CYP for endangered trout significantly influenced percentage and duration of motile sperm cells. Based on these results, fish sperm for in vitro assays can be used due to be practical, cheap and quick for defining the range of concentration allowed in natural ecosystems.

\section{ACKNOWLEDGEMENT}

This work was supported by the Scientific Research Projects of TURKEY (Project No: KTÜBAP-FHD2016-5697). The authors thank to Mehmet KUTLUYER and Aziz KUTLUYER who helped us conduct the research. In addition, the authors are grateful to Devrim ALTINTASS for gently provide the facilities and experimental fish.

\section{CONFLICT OF INTEREST}

The authors declare no conflict of interest.

\section{ABBREVIATIONS}

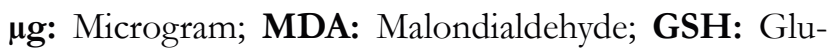
tathione; SOD: Superoxide Dismutase; CAT: Catalase; GSH-Px: Glutathione Peroxidase; CYP: Cypermethrin; ROS: Reactive Oxygen Substances; LPO: Lipid Peroxidation; PUFA: Polyunsaturated Fatty Acids.

\section{REFERENCES}

1. Taju G, Abdul Majeed S, Nambi KSN, Farook MA, Vimal S, Sahul Hameed AS. in vitro cytotoxic, genotoxic and oxidative stress of cypermethrin on five fish cell lines. Pest Biochem Physiol 2014;113:15-24. Doi: https://doi. org/10.1016/j.pestbp.2014.06.006.

2. Bonansea RI, Wunderlin DA, Amé MV. Behavioral swimming effects and acetylcholinesterase activity changes in Jenynsia multidentata exposed to chlorpyrifos and cypermethrin individually and in mixtures. Ecotox Environ Safe 2016;129:311-9. Doi: 10.1016/j.ecoenv.2016.03.043

3. Brodeur JC, Malpel S, Anglesio AB, Cristos D, D'Andrea MF, Poliserpi MB. Toxicities of glyphosate- and cypermethrin-based pesticides are antagonic in the tenspotted livebearer fish (Cnesterodon decemmaculatus). Chemosphere. 2016;155:429-35. Doi: 10.1016/j.chemosphere.2016.04.075.

4. Poley JD, Braden LM, Messmer AM, Whyte SK, Koop Ben F, Fast MD. Cypermethrin exposure induces metabolic and stress-related gene expression in copepodid salmon lice (Lepeophtheirus salmonis). Comp. Biochem. Physiol. Part D: Genom. Prot. 2016;20:74-84. Doi: 10.1016/j. cbd.2016.08.004.

5. Dutta MK, Sengar N, Kamble N, Banerjee K, Minhas N, Sarkar B. Image processing based technique for classification of fish quality after cypermethrine exposure. LWT-Food Sci Technol 2016;68:408-17. Doi: 10.1016/j.Iwt.2015.11.059. 
6. Kidd H, James DR. The Agrochemicals Handbook, third edition, Royal Society of Chemistry Information Services, Cambridge, UK, 1991, pp. 2-13.

7. Gökalp Muranli FD, Güner U. Induction of micronuclei and nuclear abnormalities in erythrocytes of mosquito fish (Gambusia affinis) following exposure to the pyrethroid insecticide lambda-cyhalothrin. Mutat Res 2011;726(2):104-8. Doi: https://doi.org/10.1016/j.mrgentox.2011.05.004.

8. Madkour NK. Protective effect of curcumin on oxidative stress and DNA fragmentation against lambda cyhalothrin-induced liver damage in rats. J Appl Pharm Sci. 2012;2:76-81. Doi: 10.7324/JAPS.2012.21214.

9. Hussein MMA, Ahmed MM. The Th1/Th2 paradigm in lambda cyhalothrininduced spleen toxicity: The role of thymoquinone. Environ Toxicol Pharm. 2016;41:14-21. Doi: https://doi.org/10.1016/j.etap.2015.11.008.

10. Velisek J, Wlasow T, Gomulka P, Svobodova Z, Dobsikova R, Novotny L, et al. Effects of cyperhethrin on rainbow trout (Oncorhynchus mykiss). Vet Med. 2006;51(10):469-76.

11. Carriquiriborde P, Díaz J, López GC, Ronco AE, Somoza GM. Effects of cypermethrin chronic exposure and water temperature on survival, growth, sex differentiation, and gonadal developmental stages of Odontesthes bonariensis (Teleostei). Chemosphere. 2009;76(3):374-80. Doi: 10.1016/j. chemosphere.

12. Ansari RA, Rahman S, Kaur M, Anjum S, Raisuddin S. et al cytogenetic and oxidative stress-inducing effects of cypermethrin in freshwater fish, Channa punctata Bloch. Ecotox Environ Safe 2011;74(1):150-6. Doi: 10.1016/j. ecoenv.2010.08.036.

13. Sthephanson RR. Aquatic toxicology of cypermethrin. I. Acute toxicity to some freshwater fish and invertebrates in laboratory tests. Aquat Toxicol. 1982;2(3):175-85. Doi: https://doi.org/10.1016/0166-445X(82)90014-5.

14. Arslan H, Özdemir S, Altun S. Cypermethrin toxication leads to histopathological lesions and induces inflammation and apoptosis in common carp (Cyprinus carpio L.). Chemosphere. 2017;180:491-9. Doi:10.1016/j. chemosphere.2017.04.057.

15. Maryoung LA, Lavado R, Schlenk D. Impacts of hypersaline acclimation on the acute toxicity of the organophosphate chlorpyrifos to Salmonids. Aquat Toxicol. 2014;152:284-90. Doi: http://dx.doi.org/10.1016/j. aquatox.2014.04.017.

16. Kocabaş M, Bascinar N. The effect of salinity on spotting features of Salmo trutta abanticus, S. trutta fario and S. trutta labrax of cultured. Iran J Fish Sci. 2013;12:723-32.

17. Islam SM, Akhter T. Tale of fish sperm and factors affecting sperm motility: A review. Adv Life Sci. 2011;1(1):1-19. Doi: 10.5923/j.als.20110101.03.

18. Öğretmen F, Inanan BE, Kutluyer F. Combined effects of physicochemical variables ( $\mathrm{pH}$ and salinity) on sperm motility: characterization of sperm motility in European sea bass Dicentrarchus labrax. Mar Freshw Behav Physiol. 2016;49(3):217-22. doi: http://dx.doi.org/10.1080/10236244.2016.1 163838.

19. Dzyuba V, Cosson J, Dzyuba B, Yamaner G, Rodina M, Linhart O. The antioxidant system of seminal fluid during in vitro storage of sterlet Acipenser ruthenus sperm. Fish Physiol Biochem. 2016;42(2):563-8. doi: 10.1007/ s10695-015-0159-1.

20. Kutluyer $F$, Erisir $M$, Benzer $F$, Ögretmen F, Inanan BE. The in vitro effect of Lambda-cyhalothrin on quality and antioxidant responses of rainbow trout Oncorhynchus mykiss spermatozoa. Environ Toxicol Pharmacol. 2015;40(3):855-60. doi: http://dx.doi.org/10.1016/j.etap.2015.09.018.

21. Jaensson A, Scott AP, Moore A, Kylin H, Olsen KH. Effects of a pyrethroid pesticide on endocrine responses to female odours and reproductive behaviour in male parr of brown trout (Salmo trutta L.). Aquat Toxicol. 2007;81(1):1-9. Doi: https://doi.org/10.1016/j.aquatox.2006.10.011.

22. Benedetto A, Brizio P, Squadrone S, Scanzio T, Righetti M, Gasco L, et al. Oxidative stress related to chlorpyrifos exposure in rainbow trout: Acute and medium term effects on genetic biomarkers. Pest Biochem Physiol. 2016;129:63-9. Doi: https://doi.org/10.1016/j.pestbp.2015.10.019.

23. Campagna C, Guillemette C, Paradis R, Sirard MA, Ayotte P. An environmentally relevant organochlorine mixture impairs sperm function and embryo development in the porcine model. Biol Reprod. 2002;67(1):80-7.

24. Moore A, Waring CP. The effects of a synthetic pyrethroid pesticide on some aspects of reproduction in Atlantic salmon (Salmo salar L.), Aquat Toxicol. 2001;52(1):1-12. Doi: https://doi.org/10.1016/S0166-445X(00)00133-8.
25. Singh PB, Singh V. Bioaccumulation of hexachlorocyclohexane, dichlorodiphenyltrichloroethane, and estradiol-17b in catfish and carp during pre-monsoon season in India. Fish Physiol Biochem. 2008;34(1):25-36.

26. Lahnsteiner F, Berger B, Weismann T, Patzner RA. Determination of semen quality of the rainbow trout, Oncorhynchus mykiss, by sperm motility, seminal plasma parameters, and spermatozoal metabolism. Aquaculture. 1998;163(1-2):163-81. Doi: https://doi.org/10.1016/S0044-8486(98)00243-9.

27. Placer ZA, Cushman LL, Johson BC. Estimation of product of lipid peroxidation (malonyldialdehyde) in biochemical systems. Anal Biochem. 1966;16(2):359-64.

28. Sun Y, Oberley WL, LI Y. A simple method for clinical assay of superoxide dismutase. Clin Chem. 1988;34(3):497-500.

29. Matkovics B, Szabo I, Varga IS. Determination of enzyme activities in lipid peroxidation and glutathione pathways. Laboratoriumi Diagnosztika. 1988;15:248-50.

30. Aebi H. Catalase. In: Bergmeyer, H.U. (Eds.), Methods of Enzymatic Analysis. Academic press, London. 1984;671-84.

31. Chavan S, Sava L, Saxena V, Pillai S, Sontakke A, Ingole D. Reduced Glutathione: Importance of specimen collection. J Clin Biochem. 2005;20(1):150-2.

32. Lowry OH, Rosenbrough NJ, Farr AL, Randall RJ. Protein measurements with the folin phenol reagent. J Biol Chem. 1951;193(1):265-75.

33. Atamanalp M, Cengiz M. The effects of sublethal doses of a synthetic pyrethroid (cypermethrine) on haemoglobin, haematocrit and sediment of Capoeta capoeta capoeta (Güldenstaedt, 1772). E U J Fish Aquat Sci. 2002;19(1-2):169-75.

34. Köprücü K, Mişe YS, Şeker E. Effects of cypermethrin on antioxidant status, oxidative stress biomarkers, behavior, and mortality in the freshwater mussel Unio elongatulus eucirrus. Fish Sci. 2010;76(6):1007-13. Doi: 10.1007/ s12562-010-0293-8.

35. Betancourt M, Resendiz A, Fierro ECR. Effect of two insecticides and two herbicides on the porcine sperm motility patterns using Computer-Assisted Semen Analysis (CASA) in vitro. Reprod Toxicol. 2006;22(3):508-12. Doi: 10.1016/j.reprotox.2006.03.001.

36. Kutluyer F, Benzer F, Erisir M, Ögretmen F, Inanan BE. The in vitro effect of cypermethrin on quality and oxidative stress indices of rainbow trout Oncorhynchus mykiss spermatozoa. Pest Biochem Physiol. 2016;128:63-7. Doi: http://dx.doi.org/10.1016/j.pestbp.2015.10.001.

37. Aitken RJ, Roman SD. Antioxidant systems and oxidative stress in the testes. Oxid Med Cell Longev. 2008;1(1):15-24.

38. Martínez-Páramo S, Diogo $\mathrm{P}$, Dinis MT, Herráez MP, Sarasquete C, Cabrita E. Incorporation of ascorbic acid and a-tocopherol to the extender media to enhance antioxidant system of cryopreserved sea bass sperm. Theriogenology. 2012;77(6):1129-36. Doi: 10.1016/j. theriogenology.2011.10.017.

39. Shiva M, Gautam AK, Verma Y, Shivgotra V, Doshi H, Kumar S. Association between sperm quality, oxidative stress, and seminal antioxidant activity. Clin Biochem. 2011;44(4):319-24. Doi: 10.1016/j.clinbiochem.2010.11.009.

40. Zhou BS, Liu WH, Siu WHL, O'Toole D, Lam PKS, Wu RSS. Exposure of spermatozoa to duroquinone may impair reproduction of the common carp (Cyprinus carpio) through oxidative stress. Aquat Toxicol. 2006;77(2):136-42. Doi: 10.1016/j.aquatox.2005.11.006.

41. Dietrich GJ, Żabowska M, Wojtczak M, Słowińska M, Kucharczyk D, Ciereszko A. Effects of different surfactants on motility and DNA integrity of brown trout (Salmo trutta fario) and common carp (Cyprinus carpio) spermatozoa. Reprod Biol. 2007;7(2):127-42.

42. Singh PB, Sahu V, Singh V, Nigam SK, Singh HK. Sperm motility in the fishes of pesticide exposed and from polluted rivers of Gomti and Ganga of north India. Food Chem Toxicol. 2008;46(12):3764-9. Doi: https://doi.org/10.1016/j. fct.2008.09.066.

43. Li ZH, Li P, Rodina M, Randak T. Effect of human pharmaceutical Carbamazepine on the quality parameters and oxidative stress in common carp (Cyprinus carpio L.) spermatozoa. Chemosphere. 2010b;80(5):530-4. Doi: 10.1126/science.1115035.

44. Fadakar MF, Mojazi AB, Mirvaghefi AR, Nemtollahi MA. In vitro Effects of diazinon on male reproductive tissue and sperm motility of Caspian Kutum (Rutilus frisii kutum). Res J Environ Toxicol. 2011;5(2):108-16. Doi: 10.3923/ rjet.2011.108.116. 

relevant concentrations of vinclozolin on quality, DNA integrity, and antioxidant responses of sterlet Acipenser ruthenus spermatozoa. Chem Biol Interact 2013;203(2):377-85. Doi: 10.1016/j.cbi.2013.01.004.

46 on functional competence, genomic integrity, and oxidative stress indices of sterlet (Acipenser ruthenus) spermatozoa. Toxicol In vitro. 2013;27(6):16129. Doi: 10.1016/j.tiv.2013.04.002

47. Shaliutina O, Shaliutina-Kolešová A, Lebeda I, Rodina M, Gazo I. The in vitro effect of nonylphenol, propranolol, and diethylstilbestrol on quality parameters and oxidative stress in sterlet (Acipenser ruthenus) spermatozoa". Toxicol in vitro. 2017;43:9-15. Doi: https://doi.org/10.1016/j.tiv.2017.05.006.

48. Rurangwa E, Biegniewsk A, Slominska E, Skorkowski EF, Ollevier F. Effect of tributyltin on adenylate content and enzyme activities of teleost sperm: a biochemical approach to study the mechanisms of toxicant reduced spermatozoa motility. Comp Biochem Physiol Part C. 2002;131(3):335-44 Doi: 10.1016/S1532-0456(02)00019-4.

49. Lakhani SA, Masud A, Kuida K, Porter-Jr GA, Booth CJ, Mehal WZ, et al. Caspases 3 and 7: Key mediators of mitochondrial events of apoptosis. Science. 2006;311(5762):847-51. Doi: 10.1126/science.1115035.

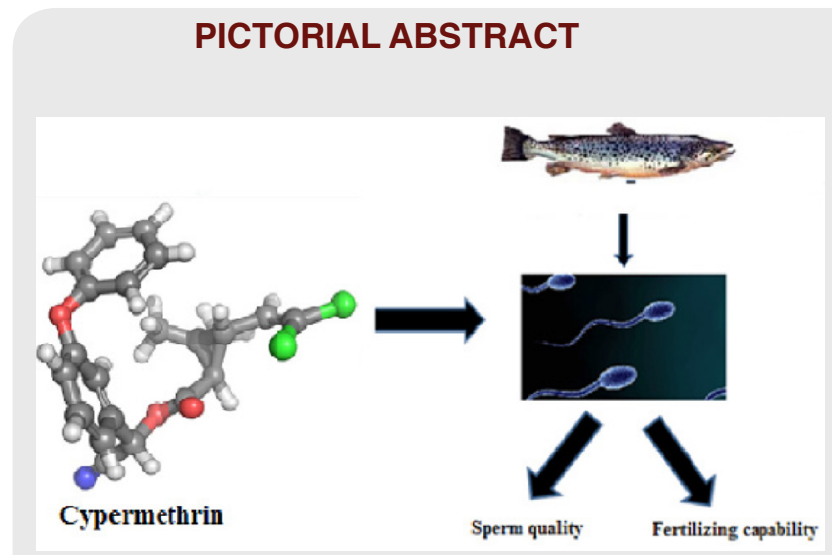

\section{SUMMARY}

- Motility rate and duration of spermatozoa significantly decreased with exposure to cypermethrin.

- GSH-Px activity of spermatozoa increased significantly.

- MDA, CAT and GSH and levels of endangered trout (S. coruhensis) spermatozoa were increased by CYP and, while GSH-Px and SOD activity decreased.

\section{About Authors}

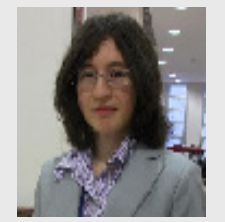

Dr. Filiz Kutluyer: She is working as a Research assistant Doctor in Munzur University, Fisheries Faculty. Her main research interests focus on sperm quality and sperm cryopreservation. She has 15 years of teaching and research experience which is highlighted in different national and international journals.

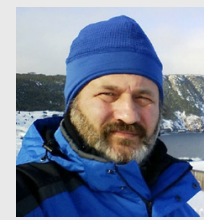

Assoc. Prof. Dr. Mehmet Kocabas: He is working as Assoc. Prof. Dr. in Karadeniz Technical University, Faculty of Forestry, Department of Wildlife Ecology and Management. Her main research interests focus on Salmonids, fisheries, aquaculture, pish population and management. She has 25 years of teaching and research experience which is highlighted in different national and international journals.

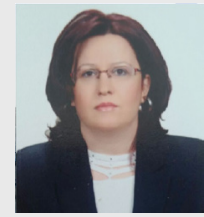

Prof. Dr. Mine Erisir: She is working as a Professor Doctor in Firat University, Department of Basic Science of Veterinary Faculty. Her main research interests focus on enzymes and biochemistry, antioxidants, pharmacology. She has 20 years of teaching and research experience which is highlighted in different national and international journals.

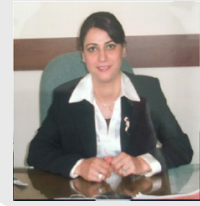

Prof. Dr. Fulya Benzer: She is working as a Professor Doctor in Munzur University, Department of Food Engineering. Her main research interests focus on biochemistry, antioxidants, pharmacology and Nitric oxide assays. She has 20 years of teaching and research experience which is highlighted in different national and international journals.

Cite this article: Kutluyer F, Kocabas M, Erisir M, Benzer F. Cypermethrin-Induced in vitro Alterations on Oxidative Stress and Quality of Salmo coruhensis Spermatozoa. Indian J of Pharmaceutical Education and Research. 2018;52(4S):S71-S76. 